\title{
Chondrichthyes species in deep waters of the Mediterranean Sea*
}

\author{
LETIZIA SION ${ }^{1}$, ANNA BOZZANO², GIANFRANCO D'ONGHIA ${ }^{1}$, \\ FRANCESCA CAPEZZUTO ${ }^{1}$ and MICHELE PANZA ${ }^{1}$
}

${ }^{1}$ Dipartimento di Zoologia, Università degli Studi, Via E. Orabona 4, 70125 Bari, Italy. E-mail: 1.sion@biologia.uniba.it

${ }^{2}$ Institut de Ciències del Mar (CSIC), Passeig Marítim de la Barceloneta 37-49, 08039 Barcelona, Spain.

\begin{abstract}
SUMMARY: Data collected during the DESEAS survey carried out in three areas of the Mediterranean Sea (Balearic Sea, western and eastern Ionian Sea) were used to describe the distribution and abundance of chondrichthyes species at depths between 600 and $4000 \mathrm{~m}$. A total of 8 chondrichthyes species were recorded, 5 of them in the Balearic Sea, 4 in the western Ionian and 6 in the eastern Ionian. A decrease in abundance with depth was observed in each species with the exception of Centroscymnus coelolepis. The most abundant species were Galeus melastomus and Etmopterus spinax. The depth range of some species was updated. G. melastomus was caught down to $1500 \mathrm{~m}$, exhibiting a smaller-deeper pattern in females, while E. spinax was captured down to $2200 \mathrm{~m}$ with a bigger-deeper trend. Mature females of these two sharks were found between 600 and $1500 \mathrm{~m}$. A wide size-range was shown in both species. C. coelolepis was only collected in the Balearic Sea down to $2800 \mathrm{~m}$. The presence of a pregnant female was sampled from a depth of $1500 \mathrm{~m}$. The distribution of the species is discussed in the context of the present knowledge of the Mediterranean ichthyofauna.
\end{abstract}

Key words: Chondrichthyes, distribution, size structure, biology, Mediterranean Sea.

RESUMEN: ESPECIES DE CONDRICTIOS EN AGUAS PROFUNDAS DEL MAR MEDITERRÁNEO. - Para describir la distribución y abundancia de las especies de condrictios a profundidades entre 600 y $4000 \mathrm{~m}$, se utilizaron muestras de la campaña DESEAS en tres áreas del Mediterráneo (mar Balear y Iónico oriental y occidental). Se registraron un total de 8 especies de condrictios de las cuales 5 de ellas corresponden al mar Balear, 4 al Iónico occidental y 6 al Iónico oriental. En cada una de las especies se observaó un descenso de abundancia con la profundidad a excepción de Centroscymnus coelolepis. Las especies más abundantes fueron Galeus melastomus y Etmopterus spinax. Se amplió el rango de distribución de algunas especies, $G$. melastomus fue capturado por debajo de $1500 \mathrm{~m}$ y las hembras redujeron su talla con la profundidad (smaller-deeper pattern), mientras que E. spinax que se capturó hasta $2200 \mathrm{~m}$ presentó una tendencia a aumentar su tamaño con la profundidad (bigger-deeper trend). Entre 600 y $1500 \mathrm{~m}$ se encontraron hembras maduras de estas dos especies. También ambas especies presentaron un amplio rango de tallas. C. coelolepis solo se encontró en el mar Balear a $2800 \mathrm{~m}$ de profundidad. De esta especie se encontró una hembra ovada a $1500 \mathrm{~m}$. Finalmente se discute la distribución de estas especies en el marco de los conocimientos actuales de la ictiofauna mediterránea.

Palabras clave: Chondrichthyes, distribución, estructura de tallas, biología, Mediterráneo.

\section{INTRODUCTION}

The fish fauna in the Mediterranean Sea consists of 664 species, of which 86 are represented by chondrichthyes (Quignard and Tomasini, 2000). Most of

*Received February 15, 2003. Accepted November 27, 2004. the cartilaginous species are distributed on the continental shelf and on the slope. Only 4 of them dwell exclusively below $1000 \mathrm{~m}$ and only 1 exclusively at depths greater than $2000 \mathrm{~m}$ (Fredj and Maurin, 1987).

In the past two decades studies on Mediterranean chondrichthyes have increased markedly, although 
they mostly regard species distributed from the continental shelf to the upper slope (Fredj and Maurin, 1987). National and international programmes of bottom trawl surveys carried out routinely since the early 1980s have mostly contributed to the knowledge on the distribution and abundance of demersal sharks, rays and skates (Allué et al., 1985; Bertrand et al., 2000, Relini et al., 2000). Although cartilaginous fishes represent by-catch of the commercial fisheries in the Mediterranean, their importance as indicators of the "top down" effect in the food webs and overexploitation by fishery is currently under discussion for this basin (Serena et al., 2002). Their position at the top of the marine food webs in addition to their life-history k-strategies make chondrichthyes more susceptible to overfishing and to man-induced environmental changes (e.g. Stevens et al., 2000; Vacchi and Notarbartolo di Sciara, 2000). In this respect, a specific international plan of action has recently been proposed for the conservation and management of Mediterranean cartilaginous fish (Serena et al., 2002). The importance of such an action plan is linked to the awareness of the fragmentary knowledge on their biology and ecology, even for the more common species.

Even though the deep-sea exploration in the Mediterranean dates back to the end of the eighteenth century (Ryland, 2000), the main knowledge on the deep-sea cartilaginous fish of this basin concerns their taxonomy (Tortonese, 1956). Information on the occurrence, vertical distribution and abundance of chondrichthyes deeper than 1000 metres has been obtained in some areas of the western
Mediterranean (Grey, 1956; Carpine, 1970; Allué et al., 1985; Albertelli et al., 1992; Stefanescu et al., 1992a, 1992b, 1993) and in some areas of the eastern basin (e.g. Isaacs and Schwartzlose, 1975; Gilat and Gelman, 1984; Golani, 1986-87; Klausewitz, 1989; Albertelli et al., 1992; Galil and Goren, 1994; Goren and Galil, 1997; Priede and Bagley, 2000; Jones et al., 2003). Feeding ecology and sex ratio by depth have only been investigated in deep water for Galeus melastomus and Centroscymnus coelolepis in the western Mediterranean (Carrassón et al., 1992; Clò et al., 2002).

At present a comprehensive picture of the geographic and vertical distribution of deep-sea cartilaginous fish in the Mediterranean is lacking. Considering the broad area covered by the Mediterranean below $1500 \mathrm{~m}$ and the several technical limitations for sampling bathyal and abyssal fish species (Merrett and Haedrich, 1997), specific research programmes are required in order to gather scientific information on the species living in the various basins.

The DESEAS project, financed by the EC, gave the opportunity to investigate three different areas (the Balearic Sea, the western Ionian and the eastern Ionian) of the Mediterranean Sea down to $4000 \mathrm{~m}$. This paper presents the results of deep-sea chondrichthyes species collected during this research. In particular, the abundance of each species is reported as well as the depth-size trends, size structure and biological aspects on the three most abundant species: Galeus melastomus, Centroscymnus coelolepis and Etmopterus spinax.

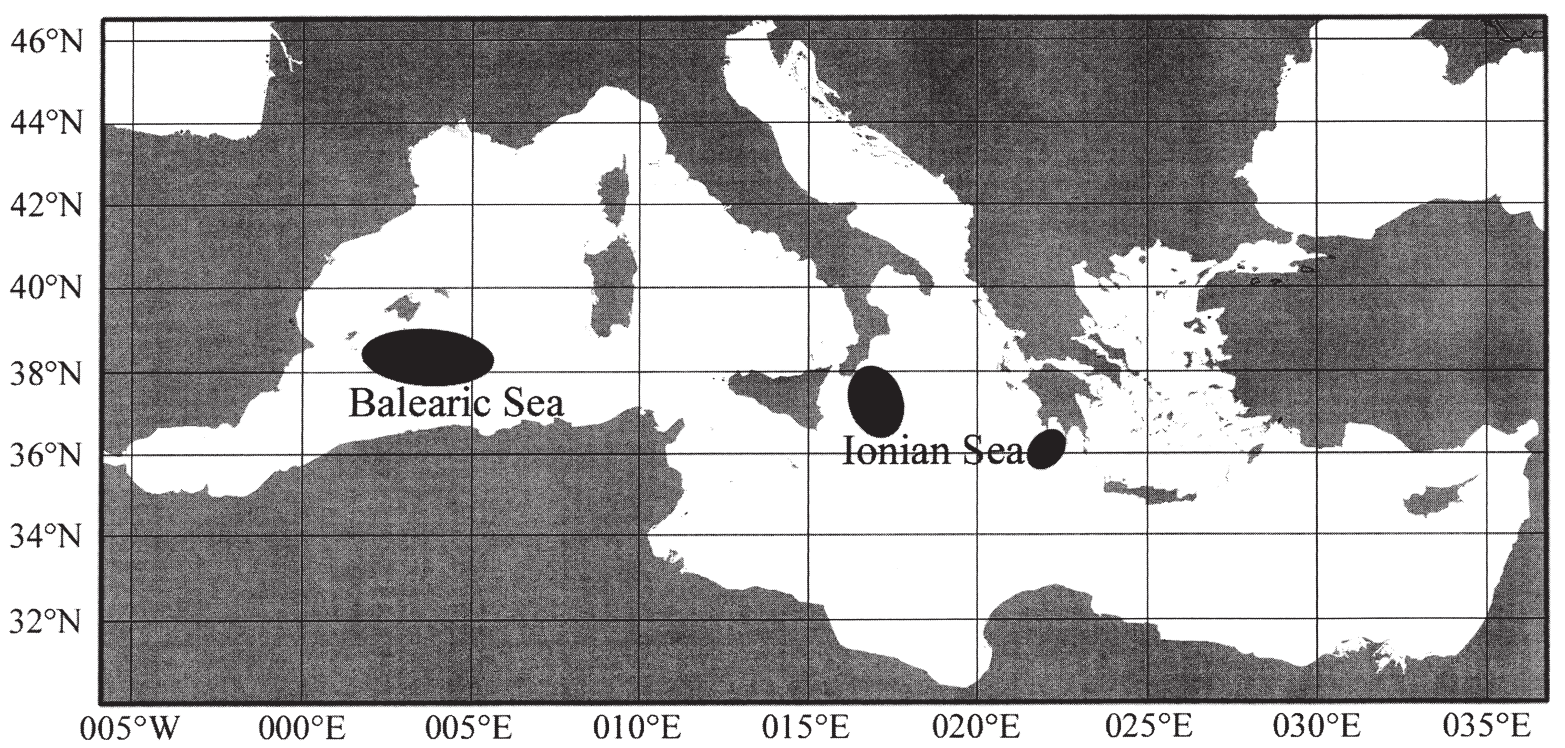

FIG. 1. - Map of the Mediterranean Sea with indication of the study areas during the DESEAS survey. 
TABLE 1. - Number of hauls by depth strata carried out in the Balearic Sea, in the western and eastern Ionian Sea during the DESEAS survey.

\begin{tabular}{cccc}
\hline $\begin{array}{c}\text { Depth stratum } \\
(\mathrm{m})\end{array}$ & Balearic area & $\begin{array}{c}\text { Western } \\
\text { Ionian Sea }\end{array}$ & $\begin{array}{c}\text { Eastern } \\
\text { Ionian Sea }\end{array}$ \\
\hline $500-999$ & 2 & 2 & 4 \\
$1000-1499$ & 2 & 2 & 2 \\
$1500-1999$ & 1 & 3 & 1 \\
$2000-2499$ & - & 1 & 1 \\
$2500-2999$ & 2 & - & - \\
$3000-3499$ & - & 1 & - \\
$3500-3999$ & - & 1 & - \\
$4000-4499$ & - & 10 & 9 \\
& 7 & & \\
Total hauls & 7 & &
\end{tabular}

\section{MATERIALS AND METHODS}

The deep-sea research cruise was carried during June 2001 in three areas of the Mediterranean Sea (Fig. 1). The area in the Balearic Sea extends from $38^{\circ} 04^{\prime} 06^{\prime \prime} \mathrm{N} 1^{\circ} 44^{\prime} 18^{\prime \prime} \mathrm{E}$ to $40^{\circ} 48^{\prime} 18^{\prime \prime} \mathrm{N} 5^{\circ} 34^{\prime} 36^{\prime \prime} \mathrm{E}$, the western Ionian area from $35^{\circ} 41^{\prime} 04^{\prime \prime} \mathrm{N}$ $16^{\circ} 24^{\prime} 48^{\prime \prime} \mathrm{E}$ to $38^{\circ} 18^{\prime} 30^{\prime \prime} \mathrm{N} 17^{\circ} 47^{\prime} 00^{\prime \prime} \mathrm{E}$, and the eastern Ionian area from $36^{\circ} 19^{\prime} 31^{\prime \prime} \mathrm{N} 21^{\circ} 54^{\prime} 23^{\prime \prime} \mathrm{E}$ to $36^{\circ} 51^{\prime} 24^{\prime \prime} \mathrm{N} 22^{\circ} 14^{\prime} 54^{\prime \prime} \mathrm{E}$.

The sampling was conducted with the otter trawl Maireta System (OTMS) using the R/V García del Cid (38 m long; 1500 HP). The OTMS (vertical opening 1.8-2 m; wing spread $14 \mathrm{~m}$ ) was trawled by a single warp and operated with a pair of rectangular iron otter boards $(1.20 \times 2.0 \mathrm{~m} ; 450 \mathrm{~kg})$. A detailed description of the net can be found in Sardà et al. (1998). The initial and final tow time were measured using a SCANMAR sonar system down to $1500 \mathrm{~m}$, and the same parameters were assumed below $1500 \mathrm{~m}$. The vessel speed and geographic position were measured using differential GPS. The trawling was carried out during daylight hours. The number of hauls carried out in each area, with the indication of the depth, is reported in Table 1. Tow duration ranged from 1 to 3 hours, but data were standardised to one hour of trawling. The results obtained in number were also standardised to one $\mathrm{km}^{2}$ for subsequent numerical processing.

Individuals were identified on board following the nomenclature reported in Whitehead et al. (1984). For each species the relationships between abundance $\left(\mathrm{N} \mathrm{km}^{-2}\right)$ and depth were computed. Total length (TL) of each individual was measured to the nearest $\mathrm{cm}$ and weight to the nearest $\mathrm{g}$. Sex and the maturity stage of the gonads were determined macroscopically according to Stehmann (1998).

The relationship between size and depth was evaluated for G. melastomus, C. coelolepis and E. spinax by means of regression analysis. The population structure by depth was performed for these species. The length-frequency distribution by maturity stage was computed for G. melastomus.

\section{RESULTS}

\section{Species composition, abundance and biomass}

During the DESEAS survey a total of 8 chondrichthyes species belonging to 5 families were collected between 600 and $2800 \mathrm{~m}$ depth. The depth range and the number of hauls in which the species were found together with the total number of the individuals caught and their total biomass are reported in Table 2. G. melastomus, Dalatias licha and E. spinax were caught in all three areas. In addition,

TABLE 2. - Chondrichtyes species collected in the Balearic Sea, in the western and eastern Ionian Sea during the DESEAS survey, with indication of depth range, number of hauls in which the species were caught (n.), total number $\left(\mathrm{N} \mathrm{h}^{-1}\right)$ and total biomass $\left(\mathrm{kg} \mathrm{h}^{-1}\right)$.

\begin{tabular}{|c|c|c|c|c|c|c|c|c|c|c|c|c|}
\hline \multirow[t]{2}{*}{ Family / Species } & \multicolumn{4}{|c|}{ Balearic Sea } & \multicolumn{4}{|c|}{ Western Ionian Sea } & \multicolumn{4}{|c|}{ Eastern Ionian Sea } \\
\hline & $\begin{array}{l}\text { Depth range } \\
(\mathrm{m})\end{array}$ & $\begin{array}{c}\text { n. } \\
\text { hauls }\end{array}$ & $\mathrm{N}$ & $\mathrm{kg}$ & $\begin{array}{l}\text { Depth range } \\
(\mathrm{m})\end{array}$ & $\begin{array}{c}\text { n. } \\
\text { hauls }\end{array}$ & $\mathrm{N}$ & $\mathrm{kg}$ & $\begin{array}{l}\text { Depth range } \\
(\mathrm{m})\end{array}$ & $\begin{array}{c}\text { n. } \\
\text { hauls }\end{array}$ & $\mathrm{N}$ & $\mathrm{kg}$ \\
\hline \multicolumn{13}{|l|}{ Hexanchidae } \\
\hline Hexanchus griseus & & & & & & & & & 1300 & 1 & 1 & 17.00 \\
\hline Scyliorhinidae & & & & & & & & & & & & \\
\hline $\begin{array}{c}\text { Galeus melastomus } \\
\text { Oxynotidae }\end{array}$ & $650-1500$ & 5 & 65 & 25.24 & $600-1500$ & 5 & 63 & 10.75 & $600-1300$ & 6 & 62 & 13.42 \\
\hline Oxynotus centrina & & & & & 800 & 1 & 1 & 0.07 & & & & \\
\hline \multicolumn{13}{|l|}{ Squalidae } \\
\hline Centrophorus granulosus & & & & & & & & & 1100 & 1 & 1 & 2.37 \\
\hline Centroscymпиs coelolepis & $1500-2800$ & 3 & 14 & 14.56 & & & & & & & & \\
\hline Dalatias licha & $802-1200$ & 2 & 2 & 6.24 & 1200 & 1 & 6 & 8.29 & 800 & 2 & 2 & 3.08 \\
\hline Etmopterus spinax & $802-1200$ & 3 & 10 & 2.65 & $600-1500$ & 4 & 13 & 0.50 & $600-2200$ & 8 & 15 & 1.74 \\
\hline \multicolumn{13}{|l|}{ Chimaeridae } \\
\hline Chimaera monstrosa & 650 & 1 & 1 & 0.02 & & & & & 800 & 2 & 2 & 0.02 \\
\hline
\end{tabular}



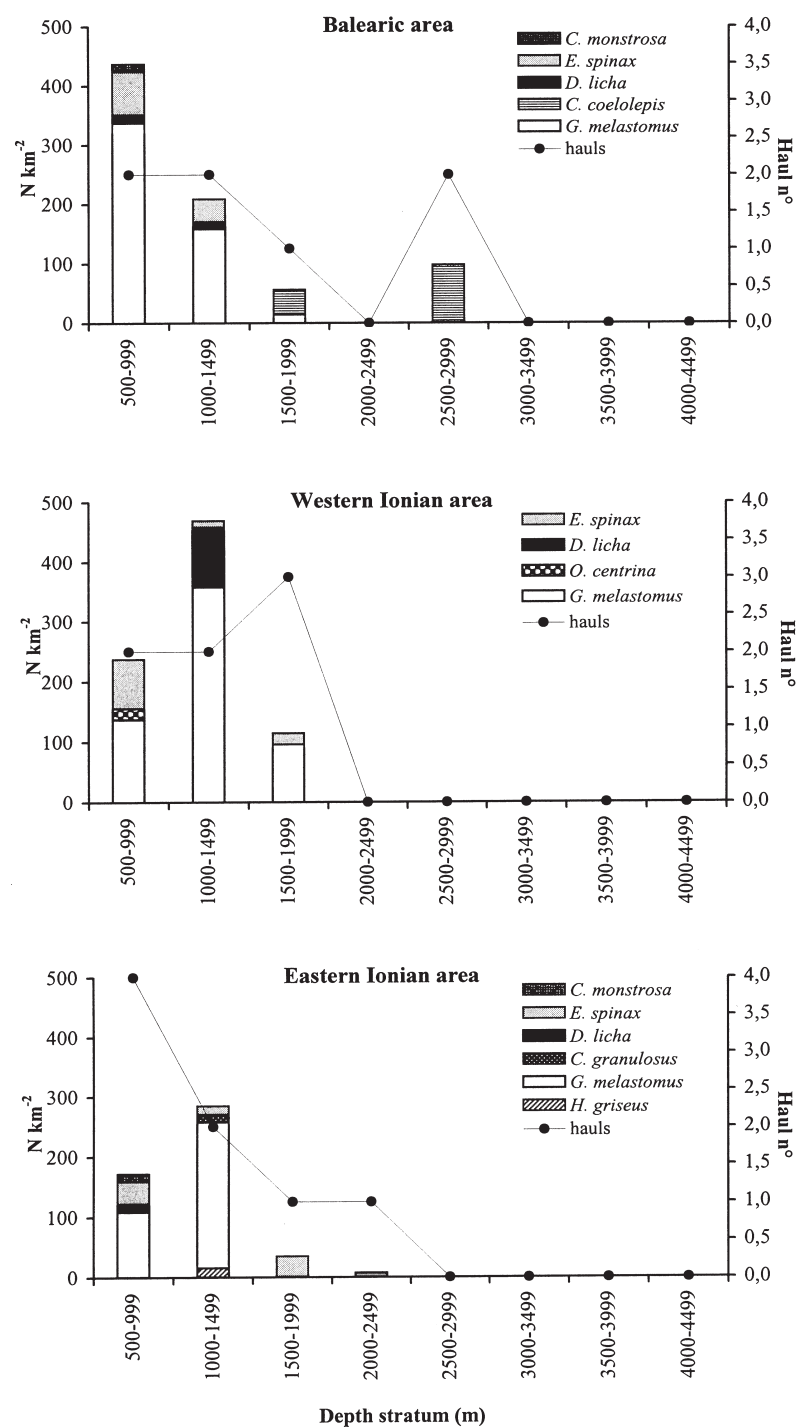

FIG. 2. - Relationship between abundance $\left(\mathrm{N} \mathrm{km}^{-2}\right)$ and depth of chondrichtyes species collected in the three study areas during the DESEAS survey. (The number of hauls where the species were collected is indicated).

one species was collected exclusively in the Balearic Sea (C. coelolepis), one in the western Ionian (Oxynotus centrina) and two in the eastern Ionian (Hexanchus griseus and Centrophorus granulosus). In all three study areas the Scyliorhinidae and Squalidae families represented about 74 and $24 \%$ respectively of the chondrichthyes collected.

The most abundant species were G. melastomus and $E$. spinax. The former was caught down to depths of $1500 \mathrm{~m}$, with the highest biomass in Balearic waters. E. spinax showed the widest vertical distribution in the eastern Ionian Sea (down to $2200 \mathrm{~m}$ ) and the greatest biomass in Spanish waters. C. coelolepis showed the deepest distribution (from 1500 to 2800 m) and was only caught in the Balearic Sea.
The relationships of abundance $\left(\mathrm{N} \mathrm{km}^{-2}\right)$ with depth of each species are shown in Figure 2. In the Balearic Sea, the abundance of G. melastomus, $D$. licha and $E$. spinax decreased with depth while $C$. coelolepis showed the highest density between 2500 and $2999 \mathrm{~m}$. In the western Ionian Sea both G. melastomus and D. licha were found to be more abundant between 1000 and 1499 m, while E. spinax was mostly captured at depths between 500 and $999 \mathrm{~m}$. In the eastern Ionian Sea G. melastomus exhibited the highest abundance in the 1000-1499 m depth stratum, whereas $D$. licha and E. spinax were mainly found in the shallower depths. The latter species also showed noteworthy density values between 1500 and $1999 \mathrm{~m}$ in both the western and eastern Ionian Sea.

\section{Biological aspects of the most abundant species}

Galeus melastomus Rafinesque, 1810

Both small and large individuals were found across the vertical gradient surveyed. Significant variations in the depth-size trend were only observed in all three areas for females (Fig. 3). The size composition of males and size by maturity stage of gonads in females are presented in Figure 4. The broadest size range was shown in the Balearic waters, with the females up to $62 \mathrm{~cm}$ and males up to $55 \mathrm{~cm}$. In this area the most abundant specimens were between 50 and $60 \mathrm{~cm}$ TL. A flat distribution with a greater number of small individuals was found in the western Ionian Sea. The largest female and male measured $55 \mathrm{~cm}$ and $52 \mathrm{~cm}$ respectively. In the eastern Ionian Sea the maximum sizes were 51 $\mathrm{cm}$ in females and $48 \mathrm{~cm}$ in males. Here the specimens were mostly distributed around the size classes of $40-48 \mathrm{~cm}$.

Immature and maturing females (stages I and II), mature females (stages III and IV) and females with egg capsules (stages V and VI) were caught in all three areas (Fig. 4). Females bearing egg capsules were caught from 800 to $1500 \mathrm{~m}$ and were between 44 and $55 \mathrm{~cm}$ in the Balearic Sea; they were collected from 800 to $1500 \mathrm{~m}$ and between 44 and $55 \mathrm{~cm}$ in the western Ionian Sea; 2 females with egg capsules of 45 and $50 \mathrm{~cm}$ TL were sampled at a depth of $600 \mathrm{~m}$ in the eastern Ionian Sea.

\section{Centroscymnus coelolepis Bocage Capello, 1864}

For Centroscymnus coelolepis, the relationship between size and depth is shown in Figure 5. The 

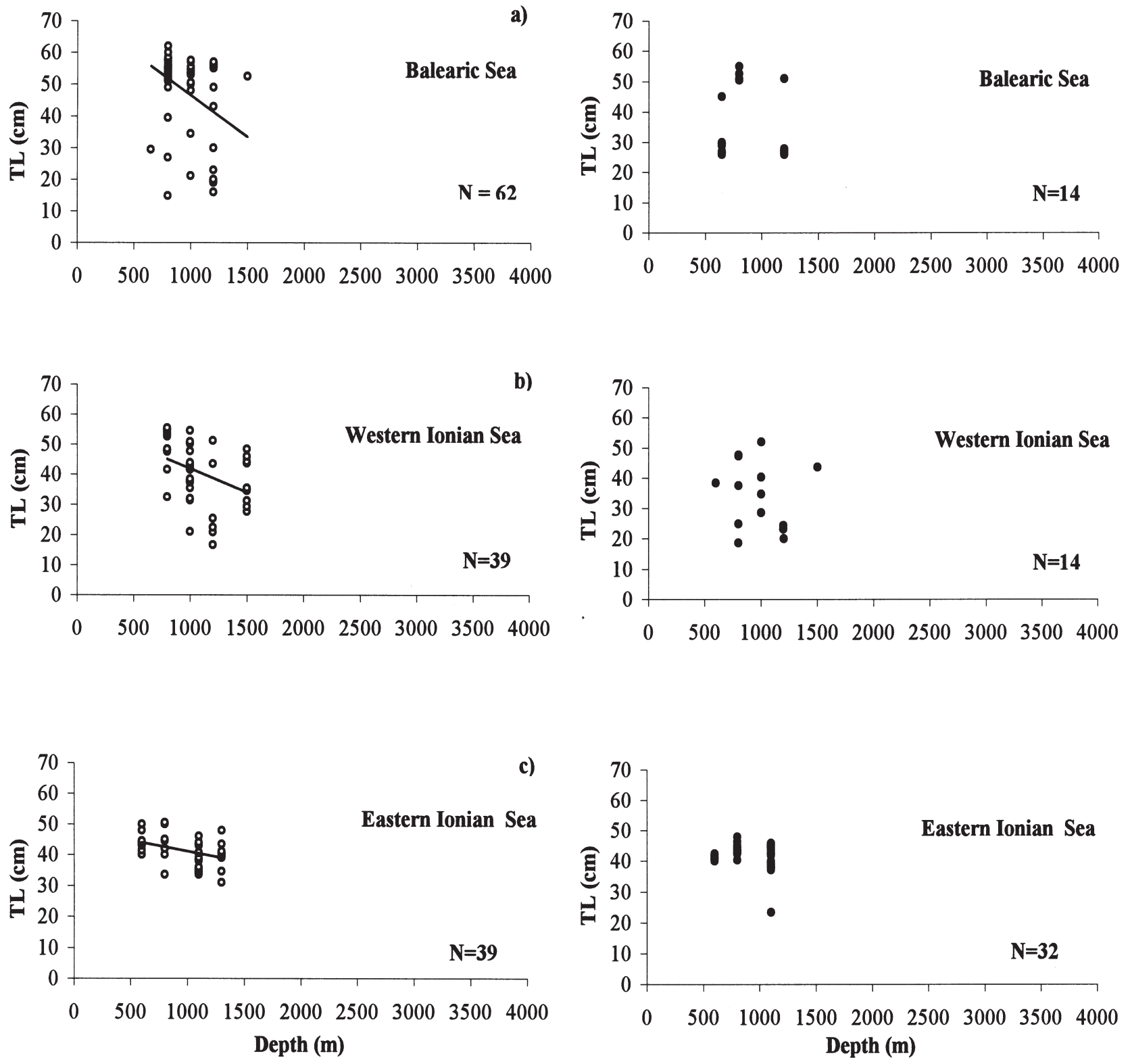

FIG. 3. - Bathymetric distribution by size of Galeus melastomus collected in the Balearic Sea, in the western and eastern Ionian Sea during the DESEAS survey. O, Females; 0 , Males. a) TL $=-0.0261$ depth $\left.+72.68 ; \mathrm{r}^{2}=0.13 ; \mathrm{p}<0.05 ; \mathrm{b}\right) \mathrm{TL}=-0.0158$ depth $+57.64 ; \mathrm{r}^{2}=0.14$; $\mathrm{p}<0.05 ; \mathrm{c}) \mathrm{TL}=-0.007$ depth $+48.11 ; \mathrm{r}^{2}=0.13 ; \mathrm{p}<0.05$.

two smallest individuals were caught in shallower waters. The size structure of this shark showed a wide range, with females and males that measured 27 to $64 \mathrm{~cm}$ and 49 to $54 \mathrm{~cm}$ respectively (Fig. 6).

The percentage of immature and maturing females was about $68 \%$. The remaining percentage consisted of 4 females at the "candle" stage (with unsegmented yolk content) and one pregnant female. The former were caught from 2500 to $2800 \mathrm{~m}$ depth and were between 59 and $64 \mathrm{~cm}$ TL. The gravid female was found at a depth of $1500 \mathrm{~m}$. It was $60 \mathrm{~cm}$ TL and contained 8 embryos that measured between 15 and 18 $\mathrm{cm}$ and weighed between 47 and $55 \mathrm{~g}$.
Etmopterus spinax (Linnaeus, 1758)

The depth-size trend of E. spinax was analysed for the whole sampled population since a low number of individuals was caught in each area. A significant increase in size with depth was only shown in males ( $p$ < 0.05) (Fig. 7). The largest specimens were caught off the Balearic Islands (34-48 cm) and the youngest individuals (10-32 cm TL) in the western Ionian. In the eastern Ionian the size-range was 11-40 cm TL (Fig. 8). The females were found to be larger than the males. In the Balearic Sea eight mature females were collected between 800 and 

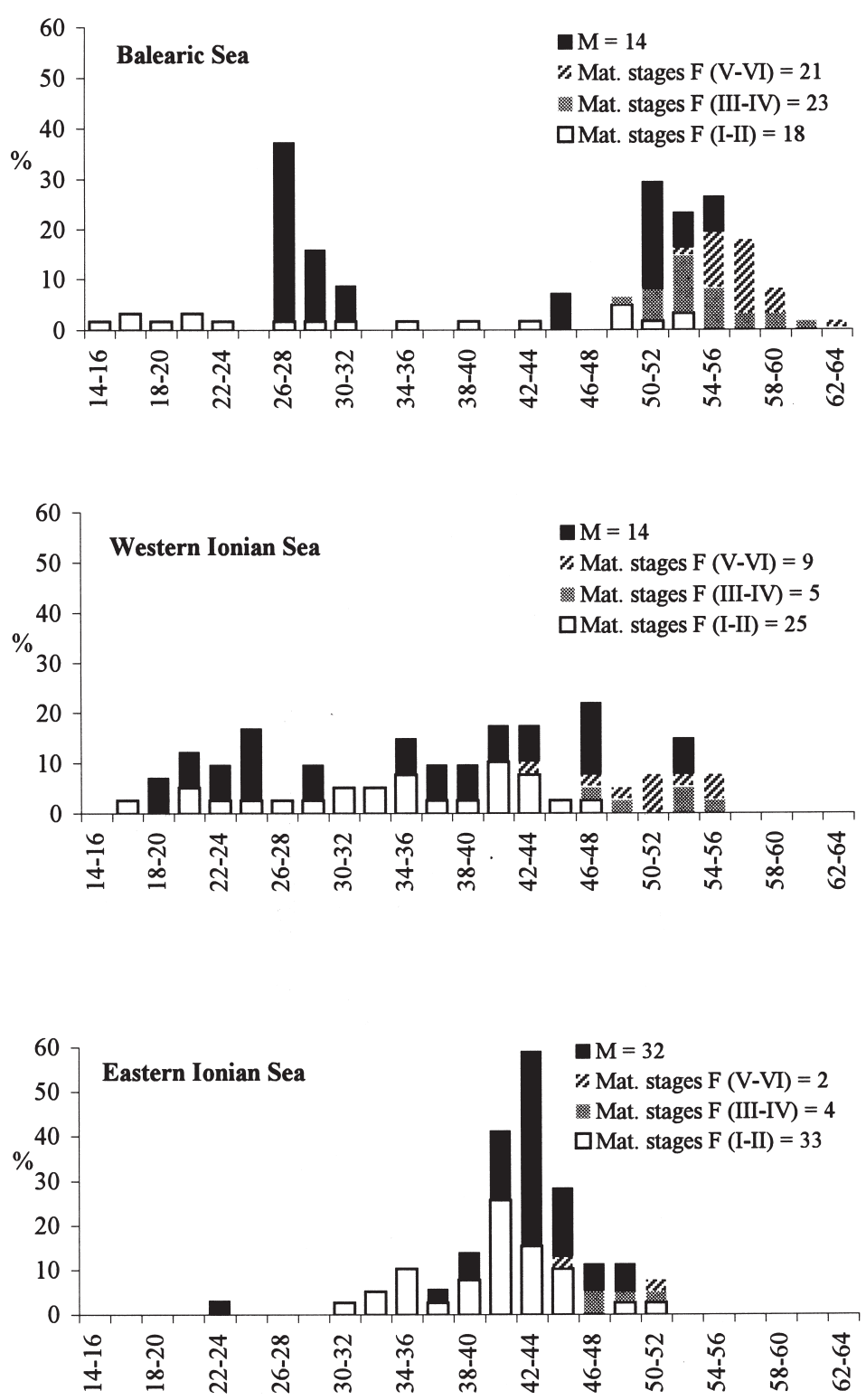

TL (cm)

FIG. 4. - Length-frequency distribution of males and females by maturity stage of Galeus melastomus collected in the Balearic Sea and in the western and eastern Ionian Sea during the DESEAS survey.

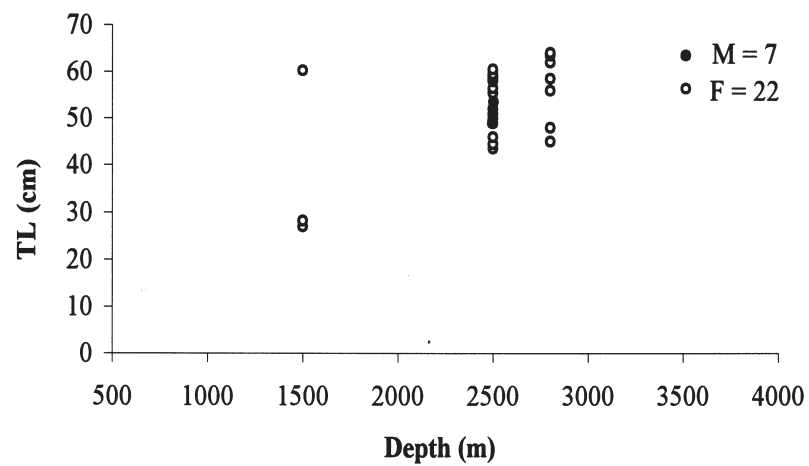

FIG. 5. - Bathymetric distribution by size of Centroscymnus coelolepis collected in the Balearic Sea during DESEAS survey.

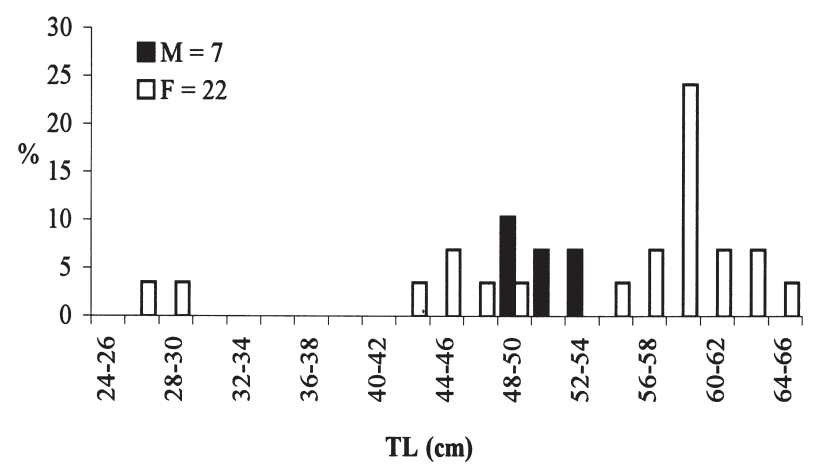

FIG. 6. - Size-frequency distribution by sex of Centroscymnus coelolepis collected in the Balearic Sea during the DESEAS survey. $\mathrm{M}$, males; F, females. 

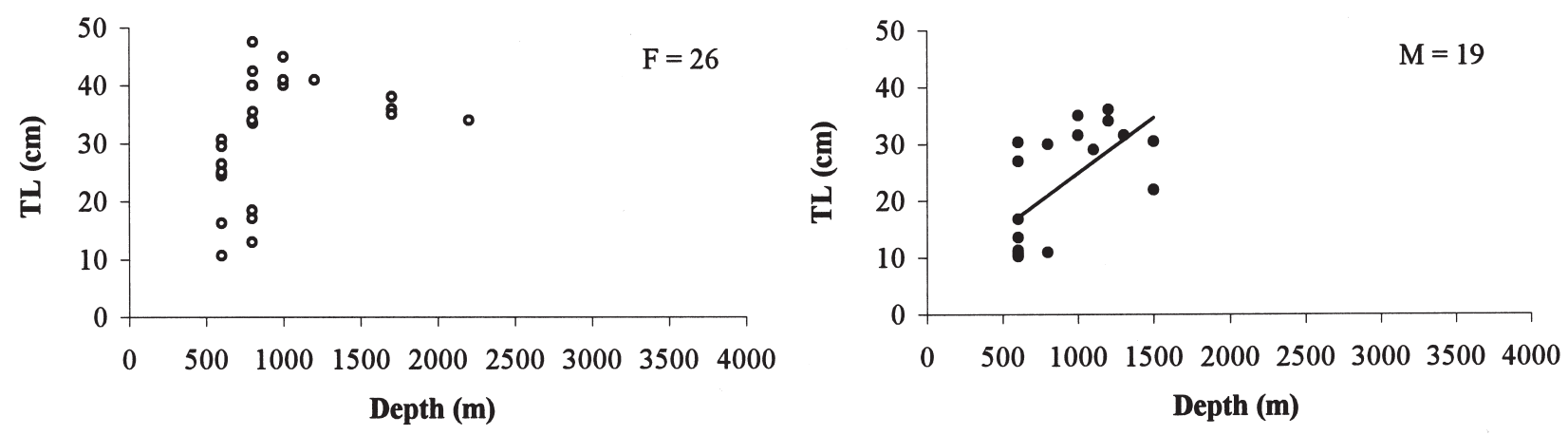

FIG. 7. - Bathymetric distribution by size of Etmopterus spinax collected in the whole study area during the DESEAS survey (F, females; M, males). Males: $\mathrm{TL}=0.0194$ depth $+5.6273 ; \mathrm{r}^{2}=0.40 ; \mathrm{p}<0.05$.
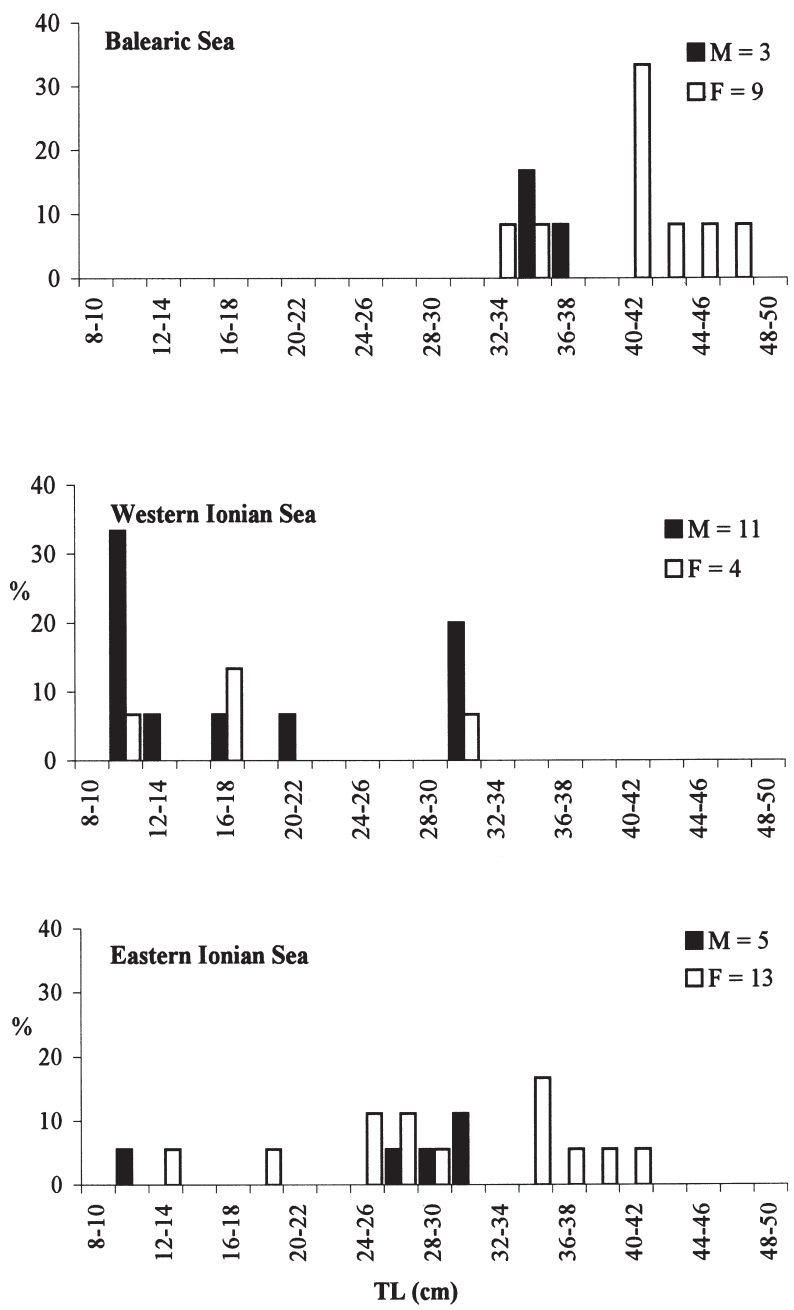

FIG. 8. - Size-frequency distribution by sex of Etmopterus spinax collected in the Balearic Sea and in the western and eastern Ionian Sea during the DESEAS survey. $\mathrm{M}$, males; $\mathrm{F}$, females.

$1000 \mathrm{~m}$. In the eastern Ionian Sea one mature female was captured at a depth of $800 \mathrm{~m}$ and two ripe males were found at depths of 1100 and $1300 \mathrm{~m}$. No mature individuals were caught in the western Ionian Sea.

\section{DISCUSSION}

The DESEAS survey represents the first recent investigation on deep-sea chondrichtyes species carried out in three areas of the Mediterranean Sea with the same gear and during the same period. All the species caught in the three study areas are typically demersal species living over sandy and muddy bottoms (Fischer et al., 1987). Although a different number of species was collected in the three study transects, it is not possible to draw definite conclusions on the species diversity differences between the three Mediterranean areas from the present results. All the species collected are known in both the western and eastern Mediterranean (Compagno, 1984; Whitehead et al., 1984; Golani, 1986-87; Fischer et al., 1987; Stefanescu et al., 1992a; Relini et al., 2000; Goren and Galil, 2002; Jones et al., 2003). The differences observed in the presenceabsence between the study areas might be due to the different number of hauls carried out by depth and area and/or to the occasional findings depending on the gear used. In addition, the number of species in each area could have been increased by employing other sampling techniques with different selectivity for the cartilaginous fishes. However, the number of species collected during this study is even higher than that captured in the western Mediterranean using three types of gear with a higher number of stations (OTSB, Agassiz trawl, longline) (Stefanescu et al., 1992a).

Three species (G. melastomus, E. spinax and $D$. licha) were found in all three areas. Their distribution throughout the Mediterranean basin is well known even in deep waters (Whitehead et al., 1984; Tortonese, 1956; Stefanescu et al., 1992a; Golani, 1986-87; Jones et al., 2003). Although during this research $C$. monstrosa was not sampled in the western Ionian Sea, its occurrence has frequently been 
recorded along the southeastern Italian coasts (Matarrese et al., 1996; Relini et al., 2000). C. coelolepis was only caught in the Balearic Sea, confirming its wide vertical distribution in the western Mediterranean. In this area it was caught as far as the maximum depth of $2863 \mathrm{~m}$ (Grey, 1956) and recently down to $2853 \mathrm{~m}$ (Clò et al., 2002). In the Catalan Sea, it was previously found from about 1400 to 2300 m (Carrassón et al., 1992; Stefanescu et al., 1992b) and off the Balearic Islands down to $1800 \mathrm{~m}$ (Moranta et al., 1998). The occurrence of $C$. coelolepis in the eastern Mediterranean was recorded using lander platforms equipped with baited cameras: between 1500 and $2500 \mathrm{~m}$ in the Cretan Sea and between 2300 and $3850 \mathrm{~m}$ in the Rhodes Basin (Priede and Bagley, 2000).

C. granulosus and $H$. griseus were only collected in Greek waters, though their occurrence throughout the Mediterranean has long been known (e.g. Fischer et al., 1987). The former was captured by longline from a depth of $1400 \mathrm{~m}$ off the coast of Israel (Golani, 1986-87). The presence of both species in the eastern Mediterranean has also been recorded in underwater photographic surveys (Gilat and Gelman, 1984; Priede and Bagley, 2000; Jones et al., 2003). Gilat and Gelman (1984) recorded $C$. granulosus from 280 to $1490 \mathrm{~m}$, with a density peak at $1080 \mathrm{~m}$, and $\mathrm{H}$. griseus from a depth of $750 \mathrm{~m}$. Jones (Priede and Bagley, 2000; Jones et al., 2003) reported the occurrence of both sharks between 1500 and $2500 \mathrm{~m}$ in the Cretan Sea and between 2300 and $3850 \mathrm{~m}$ in the Rhodes Basin.

The overall highest abundance of the chondrichthyes considered during the DESEAS cruise was observed at less than $1500 \mathrm{~m}$. The abrupt decrease in abundance below this depth might reflect the reduction of food availability as reported for deep-sea fish assemblages studied in the western Mediterranean Sea (Stefanescu et al., 1993; Moranta et al., 1998). In fact, the trophic resources between the upper and middle slope benthic boundary would be mostly based on the energetic transfer system due to mesopelagic organisms, as reported in the Atlantic ocean (e.g. Gordon, 1979; Merrett and Haedrich, 1997). In this respect, G. melastomus has a diet based on epibenthic (mainly Calocaris macandreae) and benthopelagic species (euphausiids, ommastrephidae, Pasiphaea multidentata, mesopelagic fishes), while $C$. coelolepis almost exclusively consumes cephalopods and, unlike the Atlantic populations (Mauchline and Gordon, 1983), the Mediterranean ones do not show strong scavenger habits (Carrassón et al., 1992). The diet of E. spinax is mainly based on cephalopods (Wurtz and Vacchi, 1978).

The occurrence of large mobile sharks at depths greater than $1500 \mathrm{~m}$, revealed in the both western (e.g. Stefanescu et al., 1992a; present study) and eastern Mediterranean basin (e.g. Jones in Priede and Bagley, 2000; Jones et al., 2003; and in the present study), confirms the presence on the lower slope of a further trophic system based on food arriving from the upper layers of the water column, mostly represented by animals with migratory habits (Isaacs and Schwartzlose, 1975; Mahaut et al., 1990).

The abundance recorded for G. melastomus, and to a lesser extent for E. spinax, confirms that these two species are the most abundant deep-sea demersal sharks in the Mediterranean Sea (e.g. Bertrand et al., 2000; Relini et al., 2000; Baino et al., 2001). Both species are widespread in this basin, although the former is considered absent from the northern and central Adriatic. Moreover, both species were collected in deep waters of the western (Carrassón et al., 1992; Stefanescu et al., 1992b; Moranta et al., 1998) and eastern Mediterranean basin (Galil and Goren, 1994; Goren and Galil, 1997; Jones et al., 2003). The present finding of E. spinax down to $2200 \mathrm{~m}$ represents the greatest depth at which the species has been collected by trawling in the Mediterranean Sea. However, Jones et al. (2003) captured this shark in the Cretan Sea using baited traps as deep as $2230 \mathrm{~m}$. Furthermore, Jones (Priede and Bagley, 2000) recorded the presence of $E$. spinax, together with $G$. melastomus, by means of baited cameras between 2300 and $3850 \mathrm{~m}$ in the Rhodes Basin.

Catches of G. melastomus in the Balearic and western Ionian Sea consisted of both small and large individuals, as reported by Ungaro et al. (2001) for the southern Adriatic Sea. In the eastern Ionian Sea the samples only consisted of medium-large specimens. Stefanescu et al. (1994) only collected large females at depths of $1200 \mathrm{~m}$ in the Catalan Sea. With regard to the size-related depth distribution, no trend was shown in males while a decreasing size with depth was detected in females. According to Carrassón et al. (1992), the occurrence of small specimens $(<20 \mathrm{~cm})$ at depths greater than $1000 \mathrm{~m}$ was shown both in the Balearic Sea and the western Ionian Sea. However, considering that the bulk of the population on the edge of the continental shelf and on the upper slope of the western Ionian Sea consists of young individuals (Tursi et al., 1993), the 
spawning in this shark seems to occur over a wide depth range.

For E. spinax, Macpherson and Duarte (1991) indicated a general trend of increasing size with depth. Jones et al. (2003) did not find any clear depth-size trend in specimens measured photographically. In the present study a smaller-shallower pattern seems to be evident, since large individuals were captured over the whole depth range. Large specimens of $E$. spinax are also distributed in shallower waters than those investigated in this study (Sion et al., 2000). In addition, since mature females were collected in the uppermost depths, the smallershallower trend might be the result of an inshore migration of adults during the spawning period.

An increase in size with depth was shown in $C$. coelolepis. However, no definitive conclusion can be drawn due to the small number of specimens collected. Only one pregnant female of this shark was found at $1500 \mathrm{~m}$ depth. In the northeast Atlantic, pregnant females were found almost exclusively in waters shallower than $1200 \mathrm{~m}$ (Girard and Du Buit, 1999; Clarke et al., 2001). This would explain the fact that pregnant females can move to shallower bottoms to give birth. Embryo sizes are in the range reported in the literature for the Mediterranean Sea (Clò et al., 2002) and much smaller than those observed by Girard and Du Buit (1999) for the Atlantic Ocean (around $30 \mathrm{~cm}$ ). On the other hand, the maximum lengths usually recorded in the Mediterranean Sea are much smaller than those reported by these authors in the Atlantic Ocean $(122 \mathrm{~cm})$.

The distribution of the individuals in deep areas where trawling does not occur in the Mediterranean Sea makes the deep sharks less vulnerable to overexploitation. In fact, the reduction in numbers of several selachian species, mostly on the continental shelf, seems to be related to the development of trawl fishing (Bertrand et al., 2000; Relini et al., 1999, 2000). According to Stevens et al. (2000), sharks are particularly vulnerable to overexploitation because of their slower growth, delayed maturity, low fecundity and in general k-selected life-history strategies. Indeed, several species of shark and skate that once were widespread and abundant are now uncommon and rare in Italian waters (Vacchi and Notarbartolo di Sciara, 2000). Some fishing activities targeting cartilaginous fishes, such as the deep-water fishery for bluntnose sixgill shark (Hexanchus griseus) in the Italian Ionian Sea, have almost disappeared. The fact that G. melastomus and
E. spinax are the most abundant shark species in the Mediterranean and show a stable size structure from trawl fishing catches might be related to their distribution at depths that are not exploited by trawling, thus making them less vulnerable to fishing.

Considering the deep distribution of C. coelolepis, the Mediterranean population of this shark could still be pristine, though its abundance in the whole basin is completely unknown. This could also be true for other deep-water sharks which are occasionally caught as by-catch during bottom trawls, or using longlines and driftnets, indicating that further data collection in deep-water using different sampling tools is required in order to improve our knowledge on the Mediterranean deep-sea ichthyofauna.

\section{ACKNOWLEDGEMENTS}

This work was supported by the Directorate General of Fisheries of the European Commission as part of the DESEAS project (Exploratory survey to collect data of the exploited and virgin stocks of deepsea shrimp A. antennatus, of interest to the CFP Study contract 2000/39, D.G. XIV).

\section{REFERENCES}

Albertelli, G., P.M. Arnaud, N. Della Croce, N. Drago and A. Eleftheriou. - 1992. The deep Mediterranean macrofauna caught by traps and its trophic significance. C.R. Acad. Sci. Paris, t. 315, Série III: 139-144.

Allué, C., J.A. Rucabado, D. Lloris and R. Allué. - 1985. Contribución al conocimiento de la ictiofauna abisal del Mediterráneo español. Bull. Soc. Catal. Ictiol. Herpetol., 10: 8-13.

Baino, R., F. Serena, S. Ragonese, J. Rey and P. Rinelli. - 2001. Catch composition and abundance of elasmobranchs based on the MEDITS program. Rapp. Comm. int. Mer Médit., 36: 234.

Bertrand, J., L. Gil de Sola, C. Papaconstantinou, G. Relini and A. Souplet. - 2000. Contribution on the distribution of elasmobranchs in the Mediterranean (from the MEDITS surveys). Biol. Mar. Medit., 7(1): 385-399.

Carrassón, C., C. Stefanescu and J.E. Cartes. - 1992. Diets and bathymetric distributions of two bathyal sharks of the Catalan deep sea (western Mediterranean). Mar. Ecol. Prog. Ser., 82: 21-30.

Carpine, C. - 1970. Une expérience de chalutage profond. Bull. Inst. Océanogr. Monaco, 69 (1408): 3-16.

Clarke, M.W., P.L. Connolly and J.J. Bracken. - 2001. Aspects of reproduction of the deep water sharks Centroscymnus coelolepis and Centrophorus squamosus from west of Ireland and Scotland. J. Mar. Biol. Ass. UK, 81: 1019-1029.

Clò, S., M. Dalù, R. Davonaro and M. Vacchi. - 2002. Segregation of the Mediterranean population of Centroscymnus coelolepis (Chondrichthyes: Squalidae): a description and survey. NAFO SCR, Doc., 02/83 Serial No. N4702: 3 pp.

Compagno, L.J.V. - 1984. FAO species catalogue. Vol. 4. Sharks of the world. An annotated and illustrated catalogue of shark species known to date. FAO Fish. Synop. 125, 4, Pt.2: 251-655.

Fischer, W., M.L. Bauchot and M.R. Schneider. - 1987. Fiches FAO d'identification des espèces pour les besoins de la pêche. (Révision 1). Méditerranée et Mer Noire. Zone de pêche 37. FAO. Rome, 2: 761-1530. 
Fredj, G. and C. Maurin. - 1987. Les poissons dans la banque de données MEDIFAUNE. Application à l'étude des caractéristiques de la faune ichtyologique méditerranéenne. Cybium, 11(3): 31-139.

Galil, B.S. and M. Goren. - 1994. The deep sea Levantine fauna - new records and rare occurrences. Senckenberg. Marit., 25: 41-52.

Gilat, E. and A. Gelman. - 1984. On the sharks and fishes observed using underwater photography during a deep-water cruise in the Eastern Mediterranean. Fish. Res., 2: 257-271.

Girard, M. and M.H. Du Buit. - 1999. Reproductive biology of two deep-water sharks from the British Isles, Centroscymnus coelolepis and Centrophorus squamosus (Chondrichthyes: Squalidae). J. Mar. Biol. Ass. UK, 79: 923-931.

Golani, D. - 1986-87. On deep-water sharks caught off the Mediterranean coast of Israel. Israel J. Zool., 34: 23-31.

Gordon, J.D.M. - 1979. Lifestyle and phenology in deep sea anacanthine teleosts. Symp. Zool. Soc. London, 44: 327-359.

Goren, M. and B.S. Galil. - 1997. New records of deep-sea fishes from the Levant Basin and a note on the deep-sea fishes of the Mediterranean. Israel J. Zool., 43: 197-203.

Goren, M. and B.S. Galil. - 2002. Records of Cataetyx laticeps and Ophidion barbatum (Ophidiiformes) in the Eastern Mediterranean, with comments on the deep sea ichthyofauna. Cybium, 26(2): 150-152.

Grey, M. - 1956. The distribution of fishes found below a depth of 2000 m. Fieldana Zool., 36(2): 75-183.

Isaacs, J.D. and R.A. Schwartzlose. - 1975. Active animals of the deep-sea floor. Sci. Am., 233(4): 85-91.

Jones, E.G., A. Tselepides, P.M. Bagley, M.A. Collins and I.G. Priede. - 2003. Bathymetric distribution of some benthic and benthopelagic species attracted to baited cameras and traps in the deep eastern Mediterranean. Mar. Ecol. Prog. Ser., 251: 75-86.

Klausewitz, W. - 1989. Deep-sea and deep water fish of the eastern Mediterranean, collected during the METEOR-Expedition 1987. Senckenberg. Marit., 20(5/6): 251-263.

Macpherson, E. and C.M. Duarte. - 1991. Bathymetric trends in demersal fish size: is there a general relationship? Mar. Ecol. Prog. Ser., 71: 103-112.

Mahaut, M.L., P. Geistdoerfer and M. Sibuet. - 1990. Trophic strategies in carnivorous fishes: their significance in energy transfer in the deep-sea benthic ecosystem (Meriadzeck Terrace - Bay of Biscay). Prog. Oceanogr., 24: 223-237.

Matarrese, A., G. D'Onghia, A. Tursi and M. Basanisi. - 1996. New information on the ichthyofauna of the south-eastern Italian coasts (Ionian Sea). Cybium, 20(2): 197-211.

Mauchline, J. and J.D.M. Gordon. - 1983. Diets of sharks and chimaeroids of the Rockall Trough, northeastern Atlantic Ocean. Mar. Biol., 75: 269-278.

Merrett, N.R. and R.L. Haedrich. - 1997. Deep-sea demersal fish and fisheries. Chapman and Hall, London.

Moranta, J., C. Stefanescu, E. Massutí, B. Morales-Nin and D. Lloris. - 1998. Fish community structure and depth-related trends on the continental slope of the Balearic Islands (Algerian basin, western Mediterranean). Mar. Ecol. Prog. Ser., 171: 247-259.

Priede, I.G. and P.M. Bagley. - 2000. In situ studies on deep-sea demersal fishes using autonomous unmanned lander platforms. In: R.N. Gibson and M. Barnes (eds.), Oceanogr. Mar. Biol. Ann. Rev. 38: 357-392.

Quignard, J.P. and J.A. Tomasini. - 2000. Mediterranean fish bio- diversity. Biol. Mar. Medit., (7)3: 1-66.

Relini, G., J. Bertrand and A. Zamboni. - 1999. Synthesis of the knowledge on bottom fishery resources in Central Mediterranean, Italy and Corsica. Biol. Mar. Medit., 6, Suppl.1: $868 \mathrm{pp}$.

Relini, G., F. Biagi, F. Serena, A. Belluscio, M.T. Spedicato, P. Rinelli, M.C. Follesa, C. Piccinetti, N. Ungaro, L. Sion and D. Levi. - 2000. I Selaci pescati con lo strascico nei mari italiani. Biol. Mar. Medit., 7(1): 347-384

Ryland, J.S. - 2000. European marine biology: past, present and future. Biol. Mar. Medit., 7(1): 1-27.

Sardà, F., J.E. Cartes, J.B. Company and A. Albiol. - 1998. A Modified commercial trawl used to sample deep-sea megabenthos. Fish. Sci., 64(3): 492-493.

Serena, F., M. Vacchi, G. Relini, G. Mò, M. Costantini and G. Notarbartolo di Sciara. - 2002. Status of the application of the IPOA-SHARKS to the Mediterranean and proposal of co-ordinated initiatives aimed at further developments. Biol. Mar. Medit., 9(1): 836-851.

Sion, L., G. D'Onghia, M. Basanisi and M. Panza. - 2000. Distribuzione dei selaci sui fondi strascicabili del Mar Ionio nord-occidentale. Biol. Mar. Medit., 7(1): 455-460.

Stefanescu, C., D. Lloris and J. Rucabado. - 1992a. Deep-living demersal fishes in the Catalan Sea (western Mediterranean) below a depth of $1000 \mathrm{~m}$. J. Nat. Hist., 26: 197-213.

Stefanescu, C., D. Lloris and J. Rucabado. - 1993. Deep-sea fish assemblages in the Catalan Sea (western Mediterranean) below a depth of $1000 \mathrm{~m}$. Deep-Sea Res., 40(4): 695-707.

Stefanescu, C., B. Morales-Nin and E. Massutí. - 1994. Fish assemblages on the slope in the Catalan Sea (western Mediterranean): influence of a submarine canyon. J. Mar. Biol. Ass. UK, 74: 499-512.

Stefanescu, C., J. Rucabado and D. Lloris. - 1992b. Depth-size trends in western Mediterranean demersal deep-sea fishes. Mar. Ecol. Prog. Ser., 81: 205-213.

Stehmann, M. - 1998. Revised maturity scale for sharks, rays and chimaerids. EC FAIR Project CT 95-0655. Doc. 40: 17-21.

Stevens, J.D., R. Bonfil, N.K. Dulvy and P.A. Walker. - 2000. The effects of fishing on sharks, rays, and chimaeras (chondrichthyans), and the implications for marine ecosystems. ICES J. Mar. Sci., 57: 476-494.

Tortonese, E. - 1956. Leptocardia, Ciclostomata, Selachii - Fauna d'Italia. Calderini, Bologna.

Tursi, A., G. D’Onghia, A. Matarrese and G. Piscitelli. - 1993. Observations on population biology of Galeus melastomus Rafinesque, 1810 (Chondrichthyes, Scyliothinidae) in the Ionian Sea. Cybium, 17(3): 187-196.

Ungaro, N., G. Marano and G. Rivas. - 2001. Notes on ichthyofauna of the deep basin of the Southern Adriatic Sea. Sarsia, 86: 153-156.

Vacchi, M. and G. Notarbartolo di Sciara. - 2000. I pesci cartilaginei nei mari italiani, una risorsa che richiede urgenti misure di tutela. Biol. Mar. Medit., 7(1): 296-311.

Whitehead, P.J.P., M.-L. Bauchot, J.-C. Hureau, J. Nielsen and E. Tortonese, (eds). - 1984. Fishes of the North-eastern Atlantic and the Mediterranean. UNESCO, Paris.

Wurtz, M. and M. Vacchi. - 1978. Ricerca di cicli nictemerali nell'alimentazione di selaci batiali. Quad. Lab. Tecnol. Pesca, 3(Suppl.): 155-164. 